\title{
IoT-based Compact-Matic Drinking Water Filtration Machine
}

\author{
Bienvenido B. Abad Jr. ${ }^{1}$, Michelle M. Caranguian² ${ }^{2}$, Edward B. Panganiban ${ }^{3}$ \\ ${ }^{1}$ IBS University, Port Moresby Papua New Guinea, bbajr1981@ gmail.com \\ ${ }^{2}$ AMA Computer College, Santiago City, Isabela, Philippines, esonmichiemar@gmail.com \\ ${ }^{3}$ Isabela State University, Echague, Isabela, Philippines, ebpanganiban @ isu.edu.ph
}

\begin{abstract}
Clean and potable water is very crucial nowadays. People consume water from the sources near their places not knowing what is the quality of the water. They spend money and time in fetching water. The turbidity of the water is the only reference if the water is potable. Water Filtration is one of the ways that man discovered and used to obtain clean and drinkable water. But the available filtration machine available in the market is big enough to carry it anywhere, anytime. Therefore, the writers saw the idea to build an automatic and portable filtration machine that will answer to these problems. Through problem identification, the objectives were identified as guides in the establishment "IoT-based Compact-Matic Drinking Water Filtration Machine" for households. This device is designed to have an automatic pumping system to automatically fetch water. It is equipped with $\mathrm{pH}$ and turbidity sensors that detect the quality of the water which were the basis of this project. It can send, notify, and alarm the user with the built-in notification and alarm system. The user can also track the water quality wirelessly with the use of IoT-based application Blynk which displays the data gathered from the detection. A $12 \mathrm{~V}$ motorcycle battery powered the device which is used in many filtration systems. This study has been designed carefully and diligently reviewed to ensure its operating conditions. Data collection and testing of its reliability were accomplished through a well-planned design. The results revealed that this work is effective and will help the owners protect their homes clean, potable, and drinkable water for their families.
\end{abstract}

Key words: IoT, Drinking Water, Filter, Filtration Machine, Microcontroller, Alarm System

\section{INTRODUCTION}

Water filtration is very useful to man nowadays. It helps people to obtain clean and potable water that is free from harmful chemical and microbial contaminants. Over the years, we are at a defining moment in our community where the planet nowadays is profoundly integrated with intelligent devices that are linked remotely to one another and ultimately via the Web. The system of these physical devices or objects contained with electronics, software, sensors, and Internet connectivity that allows such devices to gather and share data provides the core for the Internet of Things ( IoT) concept. [1] The water filtration system is a method in which water travels across a water treatment plant which may include one or perhaps more filters to eliminate turbidity, taste, color, iron, or smell. History tells that water filtration helps people from the past to acquire clean and drinkable water. You have to access sophisticated filtration devices these days to eliminate potentially harmful toxins and micro-organisms. Saying that water filtration is nothing new. Indeed, even the oldest known civilizations used some form of filtration method to provide citizens with drinking water [2][3][4]. In this paper, $\mathrm{pH}$ and turbidity detection are some of its important roles in the quality of water. $\mathrm{pH}$ and turbidity detection testing are made possible through detecting different solution or liquid to compare the detection or the data to the standard quality of the water. The standard drinkable water was very important to establish the standard and effectiveness of this project.[5] The data gathered from researches stated many standard $\mathrm{pH}$ and turbidity for different kinds of liquid.[6]

The principal tool used in this paper is microcontroller integration. Microcontrollers [7] such as Arduino [8] and Raspberry pi [9] can be designed to detect water quality. This can be applied to any kind of liquid or water with mobile communication for monitoring purposes. This filtering device is designed and constructed with an embedded system and sensors [10] that aimed to secure the water quality as an aid. With such a device, people can prevent from getting sick or any illness that contaminated water could give.

\section{MATERIALS AND METHODS}

\subsection{General System Design}

This paper's basic definition is explained using figure 1 . These data are the system layouts that describe the water filtration system functionalities. Figure 1a is the diagram of the water pumping system of the device. When Water Level Sensors detect the level of the water, the data will send to Arduino MEGA which will control and trigger the relay modules which serve as a switch of $12 \mathrm{~V} \mathrm{dc}$ water pumps to fetch water. The data also activates the built-in notification and alarm system of the device. 
Bienvenido B. Abad Jr et al., International Journal of Emerging Trends in Engineering Research, 8(7), July 2020, 3887 - 3892

Figure $1 \mathrm{~b}$ illustrates the detection of $\mathrm{pH}$ and turbidity levels of the water. When it detects the data will also send to the Arduino MEGA microcontroller then it will analyze the data allowing the notification system which consists of LEDs then data also send to Blynk.

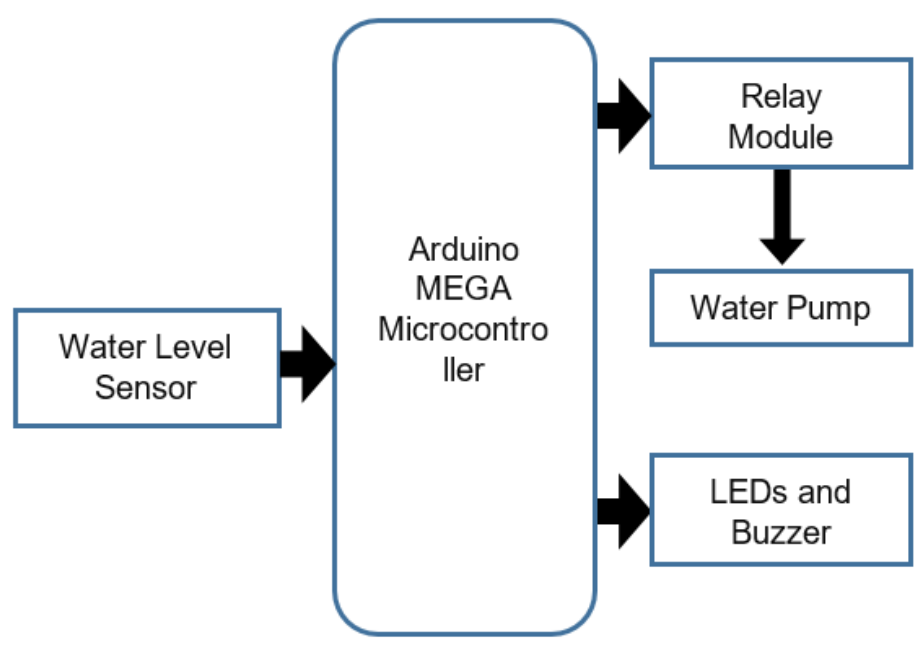

(a)

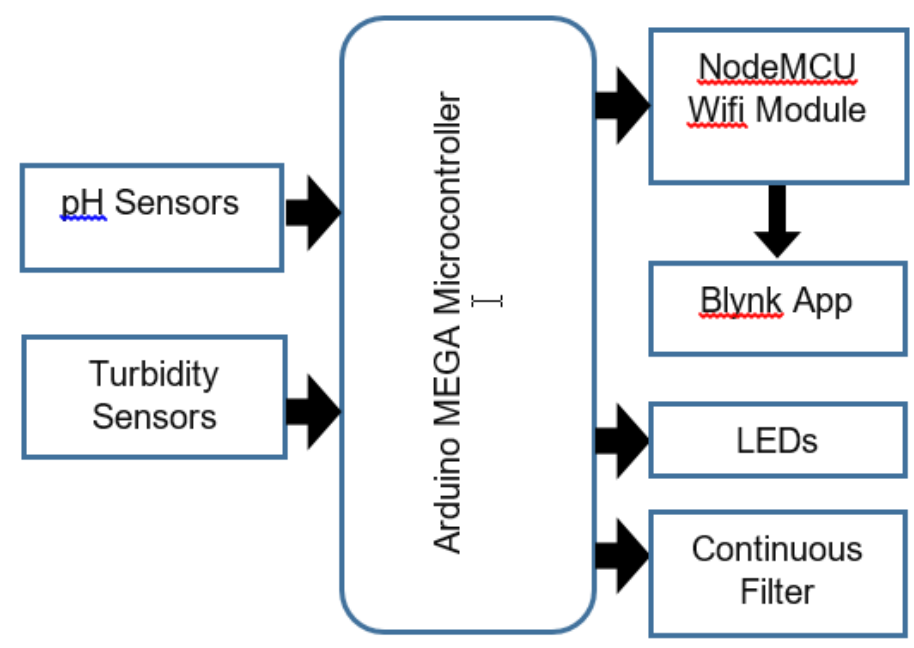

(b)

Figure 1: System Architecture of the IoT-based Compact-Matic Drinking Water Filtration Machine (a) water pumping system (b) detection of $\mathrm{pH}$ and turbidity sensors

\subsection{System Flowchart}

Figure 2 presents the detailed works of the filtration machine. It explains the whole process of how the project operates. It is composed of sensors that can detect 3 major inputs which are water level sensor, $\mathrm{pH}$ sensor, and turbidity sensor. The water level sensor that triggers the pumping system of the project. The $\mathrm{pH}$ level sensor detects the acidity or alkalinity of the water. Lastly, turbidity sensors detect the cloudiness or haziness of the water. When the input sensors will activate the built-in notification and alarm system of the device. And at the same time, the data gathered from these inputs will also send and display in an online application Blynk.
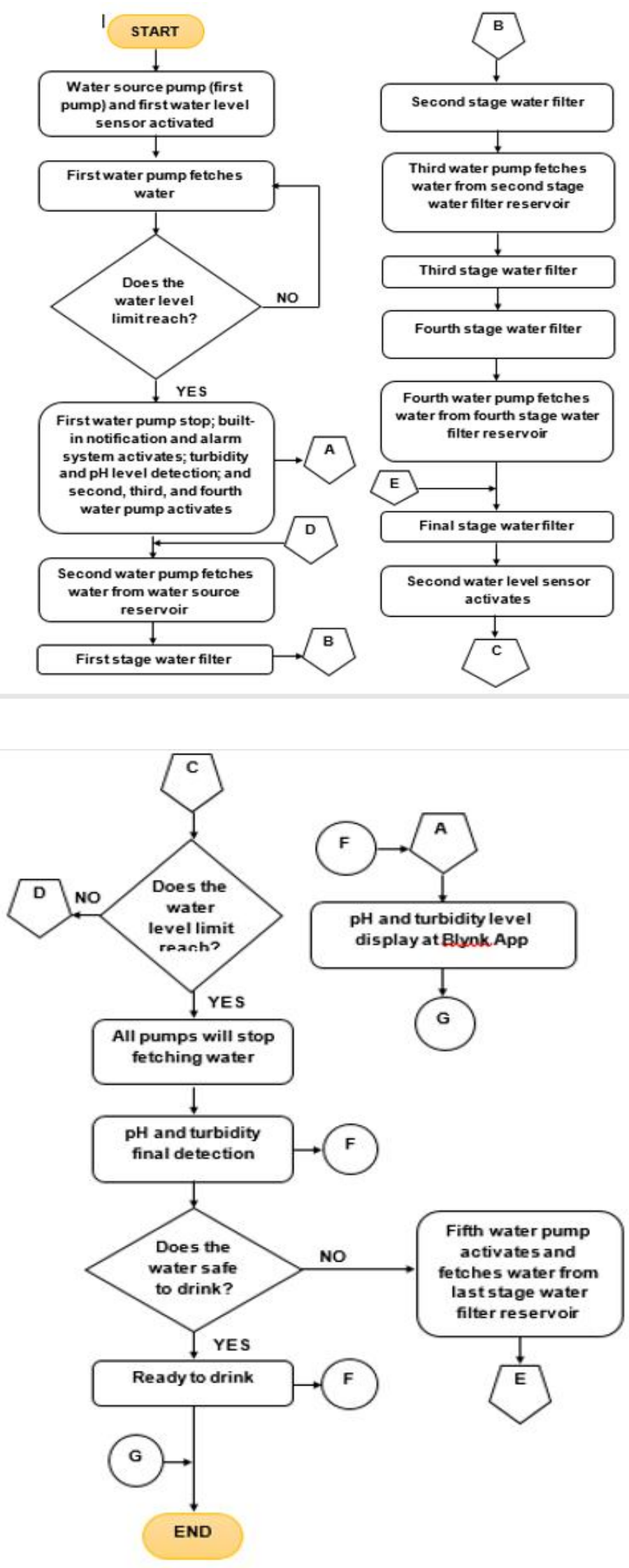

Figure 2: System Flowchart 
Bienvenido B. Abad Jr et al., International Journal of Emerging Trends in Engineering Research, 8(7), July 2020, 3887 - 3892

\subsection{Wiring Systems}

Its circuitry wiring diagram is shown in Figure 3. This shows each of the components used for the design as a reference when attaching those electronic units. The main device being used is the Arduino Mega Microcontroller which serves as the brain of all the connected components. The water level sensors, $\mathrm{pH}$ level sensors, and turbidity sensors serve ss input sensors that cause various processes and enable other devices such as NodeMCU wifi module that send a reminder to the user, LED and buzzer that behaves as the alarm and water pumps that act as the device's pumping mechanism.

\section{RESULTS AND DISCUSSION}

One essential aspect of developing this article is testing the prototype or the robot's functionalities. To arrive at a satisfactory performance it was put into many tests. Tests include unit checking, checking for approval, and testing for integration. Unit testing was developed to evaluate all of the components used and to ensure that they all function. Acceptance and integration testing ensured that everything was running as per its goals. Comprehensive tests showing the robot 's reliability are specified next tables.

\subsection{Results of Testing}

Table 1 shows the integration testing of $\mathrm{pH}$ and turbidity sensors with the wifi module and online application Blynk. It also shows the steps that the researcher did to successfully calibrated and coded the monitoring system of the device. As the results of many testing and calibration, the table shows that Blynk can receive and display the exact value of the detection using the NodeMCU wifi module.

Table 1a: Integration of $\mathrm{pH} \&$ Turbidity Detection, and Monitoring System using online application Blynk.

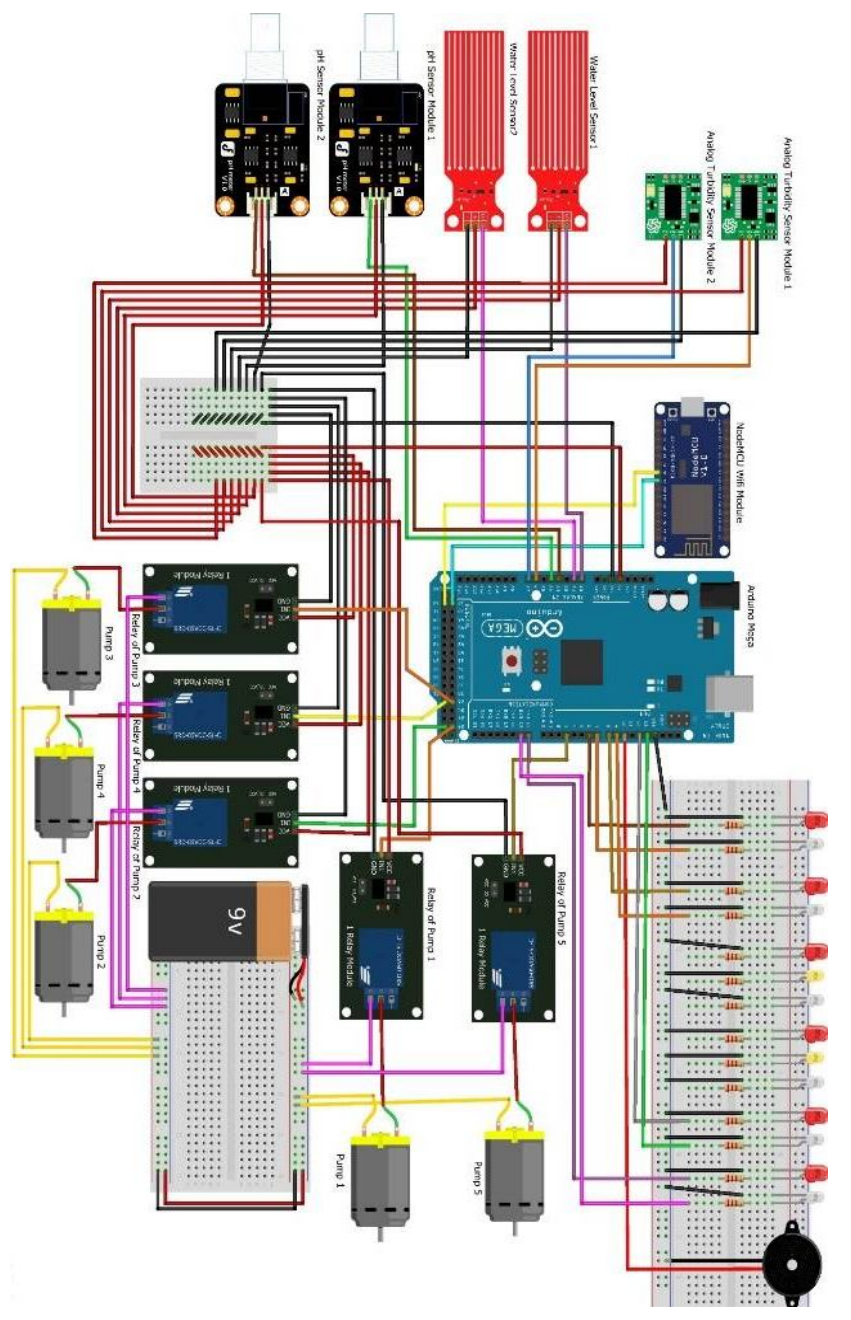

Figure 3: Wiring Diagram

\begin{tabular}{|c|c|c|c|c|c|l|}
\hline \multirow{2}{*}{ Trial } & \multicolumn{2}{|c|}{ Value to be Send } & Distance & $\begin{array}{c}\text { WiFi Module } \\
\text { Status }\end{array}$ & Blynk App & \multicolumn{1}{|c|}{ Remarks } \\
\cline { 2 - 7 } & $\mathbf{p H}$ & Turbidity & & & & \\
\hline 1 & 6.551 & 3.580 & 10 & $\begin{array}{c}\text { Not } \\
\text { Connected }\end{array}$ & Data not received & $\begin{array}{l}\text { Checked wire connection between } \\
\text { wifi module and Arduino Mega }\end{array}$ \\
\hline 2 & 6.551 & 3.580 & 10 & Not Connected & Data not received & $\begin{array}{l}\text { Checked wire and internet } \\
\text { connection }\end{array}$ \\
\hline 3 & 6.551 & 3.580 & 10 & Not Connected & Data not received & $\begin{array}{l}\text { Checked the code and internet } \\
\text { connection }\end{array}$ \\
\hline 4 & 6.551 & 3.580 & 10 & Not Connected & Data not received & $\begin{array}{l}\text { Checked the code and internet } \\
\text { connection }\end{array}$ \\
\hline 5 & 6.551 & 3.580 & 10 & Not Connected & Data not received & $\begin{array}{l}\text { Checked code and internet } \\
\text { connection }\end{array}$ \\
\hline
\end{tabular}


Bienvenido B. Abad Jr et al., International Journal of Emerging Trends in Engineering Research, 8(7), July 2020, 3887 - 3892

Table 1b: Integration of $\mathrm{pH} \&$ Turbidity Detection, and

Monitoring System using online application Blynk

\begin{tabular}{|c|c|c|c|c|c|l|}
\hline \multirow{2}{*}{$\begin{array}{c}\text { Tria } \\
\mathbf{l}\end{array}$} & \multicolumn{2}{|c|}{ Value to be Send } & Distance & WiFi Module \\
(meters) & Status & Blynk App & \multicolumn{1}{|c|}{ Remarks } \\
\cline { 2 - 7 } & $\mathbf{p H}$ & Turbidity & & & & \\
\hline 6 & 6.551 & 3.580 & 10 & Connected & Data not received & Checked code \\
\hline 7 & 6.551 & 3.580 & 10 & Connected & $\begin{array}{c}\text { Received but with only } \\
\text { 1 significant figure }\end{array}$ & Checked variable declaration \\
\hline 8 & 6.551 & 3.580 & 10 & Connected & $\begin{array}{c}\text { Received but displayed } \\
\text { not the same value }\end{array}$ & $\begin{array}{l}\text { Checked variable declaration in } \\
\text { NodeMCU code }\end{array}$ \\
\hline 9 & 6.551 & 3.580 & 10 & Connected & $\begin{array}{c}\text { Received but display } \\
\text { only 3 significant } \\
\text { figures }\end{array}$ & Checked Blynk decimal format \\
\hline 10 & 6.551 & 3.580 & 10 & Connected & $\begin{array}{c}\text { Received and display } \\
\text { the same data }\end{array}$ & Calibrated and coded successfully \\
\hline
\end{tabular}

Table 2 shows the integration of all components used in the device. The water used in this testing is from a water pump that smells like mud, with many yellow and white particles and yellowish in appearance. It also shows some of the problems encountered by the researchers which is water leaks are a common problem for every testing. And the testing proves that the device can filter this kind of water.

Table 2a: Device Test

\begin{tabular}{|c|c|c|c|c|c|}
\hline \multirow{2}{*}{ Trial } & \multicolumn{2}{|c|}{ First Detection } & \multicolumn{2}{|c|}{ Second Detection } & \multirow[t]{2}{*}{ Problems } \\
\hline & Turbidity & pH & Turbidity & pH & \\
\hline 1 & 2.578 & 8.96 & $\begin{array}{c}\text { Not } \\
\text { detected }\end{array}$ & $\begin{array}{c}\text { Not } \\
\text { detected }\end{array}$ & $\begin{array}{l}\text { - Water leaks } \\
\text { - Second detection error } \\
\text { - Built-in notification and alarm system did not activate } \\
\text { - Wifi module cannot connect } \\
\text { - No display value in Blynk app }\end{array}$ \\
\hline 2 & 3.897 & 9.56 & $\begin{array}{c}\text { Not } \\
\text { detected }\end{array}$ & $\begin{array}{c}\text { Not } \\
\text { detected }\end{array}$ & $\begin{array}{l}\text { - Water leaks } \\
\text { - Second detection error } \\
\text { - LED notifications did not respond } \\
\text { - Wifi module cannot connect } \\
\text { - No display value in Blynk app }\end{array}$ \\
\hline 3 & 4.717 & 9.041 & $\begin{array}{c}\text { Not } \\
\text { detected }\end{array}$ & $\begin{array}{c}\text { Not } \\
\text { detected }\end{array}$ & $\begin{array}{l}\text { - Second detection error } \\
\text { - Water leaks } \\
\text { - No display value in Blynk app }\end{array}$ \\
\hline
\end{tabular}


Bienvenido B. Abad Jr et al., International Journal of Emerging Trends in Engineering Research, 8(7), July 2020, 3887 - 3892

Table 2b: Device Test

\begin{tabular}{|c|c|c|c|c|l|}
\hline \multirow{2}{*}{ Trial } & \multicolumn{2}{|c|}{ First Detection } & \multicolumn{2}{|c|}{ Second Detection } & \multicolumn{1}{|}{ Problems } \\
\cline { 2 - 6 } & Turbidity & $\mathbf{p H}$ & Turbidity & $\mathbf{p H}$ & \\
\hline 4 & 3.887 & 8.403 & $\begin{array}{c}\text { Not } \\
\text { detected }\end{array}$ & $\begin{array}{c}\text { Not } \\
\text { detected }\end{array}$ & $\begin{array}{l}\text { - Second detection error } \\
- \text { Water leaks }\end{array}$ \\
\hline 5 & 4.409 & 9.172 & $\begin{array}{c}\text { Not } \\
\text { detected }\end{array}$ & $\begin{array}{c}\text { Not } \\
\text { detected }\end{array}$ & $\begin{array}{l}\text { - Second detection error } \\
- \text { - Water leaks }\end{array}$ \\
\hline 6 & 4.370 & 8.323 & 0.791 & 7.941 & $\begin{array}{l}- \text { Second turbidity sensor error } \\
- \text { Water leaks }\end{array}$ \\
\hline 7 & 0.269 & 8.981 & 1.255 & 8.180 & $\begin{array}{l}\text { - Water leaks } \\
- \text { Water still not clear }\end{array}$ \\
\hline 8 & 0.273 & 13.350 & 3.608 & 7.411 & $\begin{array}{l}\text { - Still have water leaks but minimal } \\
- \text { Clearwater }\end{array}$ \\
\hline 9 & 1.863 & 10.182 & 4.301 & 7.656 & $\begin{array}{l}\text { - Still have water leaks but minimal } \\
- \text { Clearwater }\end{array}$ \\
\hline 10 & 3.828 & 9.576 & 4.043 & 7.861 & $\begin{array}{l}\text { - No leaks } \\
- \text { Clear water } \\
- \text { Potable water }\end{array}$ \\
\hline
\end{tabular}

\subsection{Design Output}

Figure 4 shows the final design output of the filtration machine. It also displays the marked position of an integrated component within. The machine will function if the switch located at the robot 's back is turned on. Components are labeled and has its functions. Electronic components, particularly sensors, are $\mathrm{pH}$ sensors, turbidity sensors, water level sensors, filter cartridge, and containers for the water source and filtered water. The power supply used in the device is detachable for the convenience of charging

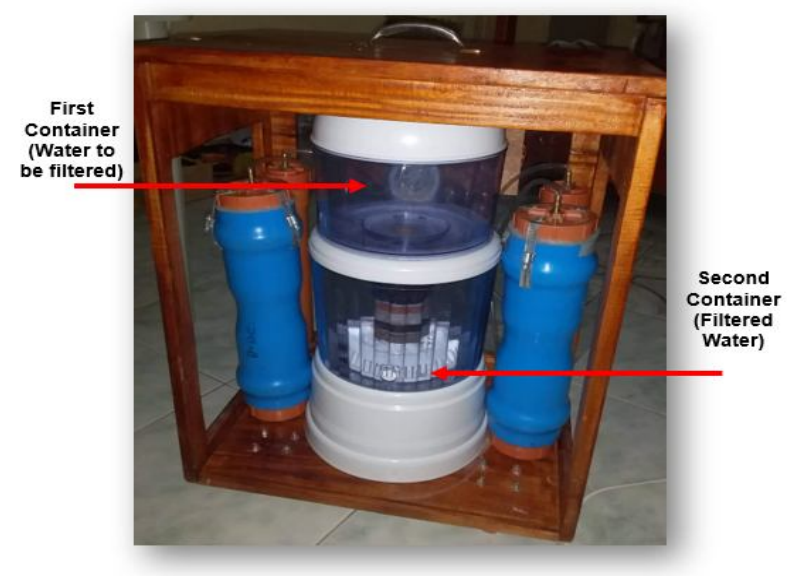

(a)

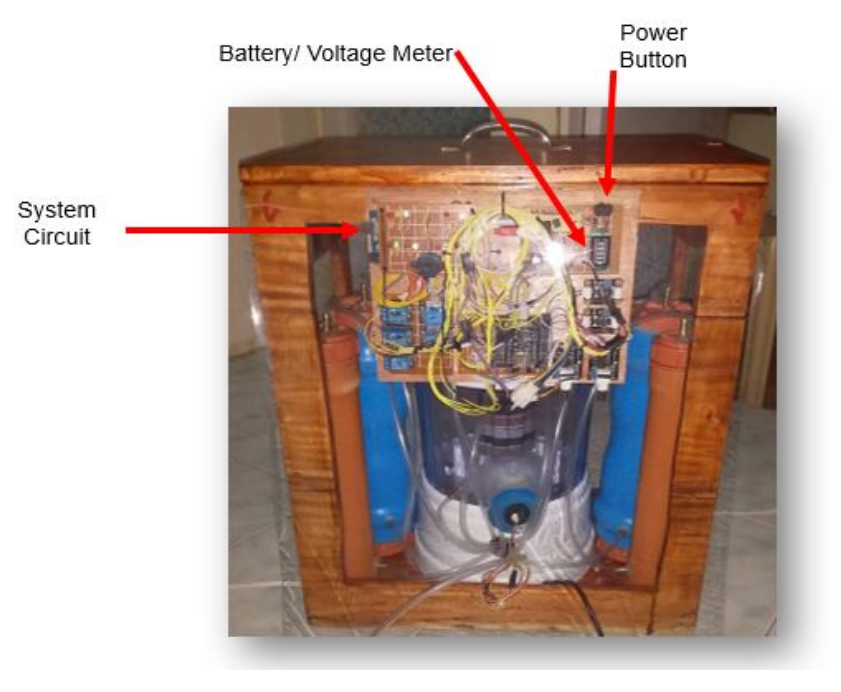

(b)

Figure 4: Final design output of the automated hazard detecting robot (a) front view (b) back view 
Bienvenido B. Abad Jr et al., International Journal of Emerging Trends in Engineering Research, 8(7), July 2020, 3887 - 3892

\section{CONCLUSION}

This paper presented the specifics of the structure of the actual filtration machine as well as the details of the experimental data showing the desired outputs of the device. The components used in this project include sensors that could detect water level, $\mathrm{pH}$, and turbidity level of the water. It is built with an automatic water pumping system that fetches water automatically. The buzzer and LED functioned as an alarm indicator for the alert system. NodeMCU wifi module sends notification and data to the person concerned. The robot has 4 wheels for the convenience of the user to carry it anywhere.

The project was made possible through the designed processes and proven working with its intended function to address the household's problem about obtaining clean and potable water. The researchers concluded that this project is working and is proven to be effective as evidence by the several tests done. Hence, this IoT-based Compact-Matic Drinking Water Filtration Machine can deal with waters coming from rain, water pump, river, and spring making it more helpful and reliable to the homeowners.

\section{Acknowledgment}

The authors would like to give special thanks to Farrah Jean Roduta, Edwil Kevin Aluit, Julius Cezar Babalcon, and Nikko Galindo for the construction of the prototype and their assistance for this paper to become successful.

\section{REFERENCES}

[1] K. Dhondge, "Internet of Things (IoT) Applications with Diverse Direct Communication Methods," Dissertation in Telecommunications and Computer Networking and Computer Science, 2016 Pelican Water, "The History of Water Filtration," Local Water News article in Pelican Water System,

https://www.pelicanwater.com/blog/the-history-of-w ater-filtration/ published March 15, 2015.

[3] World Health Organization "Drinking Water," URL:

https://www.who.int/news-room/fact-sheets/detail/dr inking-water, published 14 June 2019.

[4] Kent Ro System, "History of Water Purification," article in Kent.co.in

https://www.kent.co.in/blog/history-of-water-purifica tion/, published December 19, 2016.

[5] World Health Organization, "Guidelines for Drinking $\square$ water Quality," Fourth Edition, Incorporating the First Addendum, World Health Organization, 2017.
[6] PickYourOwn.Org., "Approximate pH of Foods and Food Products" download pdf, Accessed December 20, 2019.

[7] E. B. Panganiban, "Microcontroller-based Wearable Blood Pressure Monitoring Device with GPS and SMS Feature through Mobile App," International Journal of Emerging Trends in Engineering Research, vol. 7, no. 6, pp. 32-35, 2019. https://doi.org/10.30534/ijeter/2019/02762019

[8] E. B. Panganiban and J. C. Dela Cruz, "RFID-Based Vehicle Monitoring System," in HNICEM 2017 9th International Conference on Humanoid, Nanotechnology, Information Technology, Communication, and Control, Environment and Management, 2017, pp. 1-6. https://doi.org/10.1109/HNICEM.2017.8269489

[9] E. B. Panganiban and J. C. D. Cruz, "Rainwater level information with flood warning system using flat clustering predictive technique," in IEEE Region 10 Annual International Conference, Proceedings/TENCON, 2017, vol. 2017-Decem. https://doi.org/10.1109/TENCON.2017.8227956

[10] E. B. Panganiban, "Automated hazardous gas detecting robot using wireless sensor networks with GSM-SMS alert and fire control system for households," International Journal of Advanced Trends in Computer Science and Engineering, vol. 8, no. 3, pp. 804-809, 2019.

https://doi.org/10.30534/ijatcse/2019/72832019 